\title{
Toward a global coal mining moratorium? A comparative analysis of coal mining policies in the USA, China, India and Australia
}

\author{
Mathieu Blondeel $^{1}$ (D) Thijs Van de Graaf ${ }^{1}$
}

Received: 20 April 2017 / Accepted: 23 December 2017

(C) Springer Science+Business Media B.V., part of Springer Nature 2018

\begin{abstract}
To stop global warming at well below $2^{\circ} \mathrm{C}$, the bulk of the world's fossil fuel reserves will have to be left in the ground. Coal is the fossil fuel with the greatest proportion that cannot be used, and various advocacy groups are campaigning for a ban on the opening of new coal mines. Recently, both China and the USA implemented temporary moratoria on the approval of new coal mining leases. This article examines whether these coal mining bans reflect the emergence of a global norm to keep coal under the ground. To that end, we review recent coal mining policies in the four largest coal producers and explain them comparatively with a framework based on interests, ideas and institutions. We find that the norm of keeping coal in the ground remains essentially contested. Even in those countries that have introduced some form of a coal mining moratorium, the ban can easily be, or has already been, reversed. To the extent that the norm of keeping coal in the ground has momentum, it is primarily due to non-climate reasons: the Chinese moratorium was mostly an instance of industrial policy (aiming to protect Chinese coal companies and their workers from the overcapacity and low prices that are hitting the industry), while the USA's lease restrictions were mainly motivated by concerns over fiscal justice. We do not find evidence of norm internalisation, which means that the emerging norm fails to gain much traction amid relevant national actors and other (large) coal producing states. If proponents of a moratorium succeed in framing the issue in non-climate terms, they should have a greater chance of building domestic political coalitions in favour of the norm.
\end{abstract}

This article is part of a Special Issue on 'Fossil Fuel Supply and Climate Policy' edited by Harro van Asselt and Michael Lazarus.

Mathieu Blondeel

mathieu.blondeel@ugent.be

Thijs Van de Graaf

thijs.vandegraaf@ugent.be

1 Ghent University, Ghent, Belgium 


\section{Introduction}

For this century, to keep a global temperature increase to well below $2{ }^{\circ} \mathrm{C}$, the bulk of fossil fuel reserves must be left in the ground. Coal is the fossil fuel with the greatest proportion that cannot be used, with a global total of $82 \%$ to be left unburned before 2050 (McGlade and Ekins 2015). ${ }^{1}$ In August 2015, a global moratorium on new coal mines and mine extensions was therefore proposed by the president of Kiribati, one of the most climate vulnerable countries. $^{2}$ His proposal received the backing of several other Pacific island nations (Pacific Island Development Forum 2015), high-profile individuals such as Lord Nicholas Stern (Grantham Institute 2015), and non-governmental organisations such as the Australia Institute (TAI), which launched a dedicated 'No New Coal Mines' campaign in the very same month (Denniss 2015).

From an international relations standpoint, the call for a global coal mining moratorium can be considered as an international norm. International norms are shared understandings of what constitutes appropriate behaviour (Finnemore and Sikkink 1998). Norms are obeyed not because they are enforced, but because they are seen as legitimate (Florini 1996). Some norms are eventually codified in international agreements, but this is not always the case. For example, over the past 40 years, all but three countries have moved to phase out leaded gasoline, even though there is no global treaty banning its use (UNEP 2017). Norms are often promoted by so called norm entrepreneurs, but they can just as equally emerge 'as an ad hoc series of bottom-up events occurring simultaneously at different jurisdictional levels around the world' (Clapp and Swanston 2009, p. 316). In recent years, a set of anti-fossil fuel norms has begun to be articulated across the globe (Piggot 2017; Van de Graaf and Blondeel 2018; Green, this issue), stigmatizing the use and extraction of fossil fuels. The plea for a coal mining moratorium is part of this trend and aims to bring about a normative shift in which the opening of new coal mines would be deemed unacceptable, in the same way as norms have shifted about slavery, women's suffrage and whaling.

Yet, how realistic is a global halt on new coal mines and mine expansions? To answer this question, we examine the sources and drivers of the coal extraction policies of four countries: China, the USA, Australia and India. Our goal is not to study the civil society campaigns to keep coal in the ground or the process of norm diffusion but instead to look at the domestic politics of each country to see if there is any basis or fertile ground on which a global anti-coal mining norm might take root.

The selection of cases is justified on three grounds. First, these countries are the world's largest producers, responsible for over $72 \%$ of global coal production and holding almost two thirds of global coal reserves (see Table 1), so they are absolutely critical for a global ban on coal extraction. ${ }^{3}$ Second, they exhibit a puzzling variance in their coal mining policies, while China and the USA adopted temporary bans on the approval of new coal mining leases in 2015 and 2016, respectively, Australia and India did not. The US moratorium only applied to federal

\footnotetext{
${ }^{1}$ It is worth noting that this figure only gives an estimated $50 \%$ chance of staying with the $2{ }^{\circ} \mathrm{C}$ limit. Moreover, the figure assumes a widespread deployment of carbon capture and storage (CCS) technologies as from 2025 onwards. If CCS is not widely deployed, the amount of unburnable coal rises to 88\% (McGlade and Ekins 2015). ${ }^{2}$ The full text of President Tong's call is available from: http://www.climate.gov.ki/wp-content/uploads/2015/09 /CallForCoalMoratorium.pdf .

${ }^{3}$ Moreover, they also account for over $72 \%$ of global coal consumption, so any sign of a change in mining policies is set to create waves in the global coal market. Yet, our interest here lies with the extraction policies of the named countries, not with their coal usage policies, although we consider potential linkages between the two.
} 
Table 1 Descriptive statistics for the four selected countries

\begin{tabular}{lllll}
\hline \multicolumn{5}{c}{ Share in global coal... } \\
\\
\cline { 2 - 5 } & $\ldots$ reserves $(\%)$ & $\ldots$ production $(\%)$ & $\ldots$ consumption $(\%)$ & $\ldots$ exports $(\%)$ \\
\hline China & 21.4 & 46.1 & 50.6 & 0.7 \\
USA & 22.1 & 10.0 & 9.6 & 4.3 \\
Australia & 12.7 & 8.2 & 1.2 & 30.7 \\
India & 8.3 & 7.9 & 11.0 & $/$ \\
Total & 64.5 & 72.2 & 72.4 & 35.7 \\
\hline
\end{tabular}

All figures are for 2016. Data come from BP's Statistical Review (http:/www.bp.com/statisticalreview), except for the data on exports, which is drawn from the ITC's Trade Map (www.trademap.org). Coal exports includes coal, anthracite, bituminous coal, and coal briquettes, but excludes lignite, peat, and coke

lands, and was lifted in March 2017 by the incoming Trump administration, offering a useful degree of within-case variation that can be leveraged to search for the drivers of coal extraction policies. A third reason to focus on these 'big four' producers, is that powerful states are well positioned to advocate new norms given their large material and ideational resources. The norms these actors hold are more easily distributed because of the greater opportunity for powerful states to convince other of 'the rightness of their view' through persuasion and coercion. Other actors might also simply emulate the behaviour of powerful states because they are perceived as guiding or prestigious actors (Florini 1996).

This article proceeds as follows. The first section surveys these states' recent coal mining policies and puts them into historical perspective. It also delves into the official rationales behind the coal extraction policies. The sources for this descriptive analysis are the nationally determined contributions (NDCs), as submitted under the Paris Agreement, as well as the latest policy papers, official documents and statements of the respective countries. Next, the article moves from description to interpretation. More specifically, it attempts to explain the divergence in coal extraction policies with a classic political economy framework centred around ideas, institutions and interests (Hall 1997). In the concluding section, we reflect on what this implies for the norm's emergence on a global level and discuss some broader implications.

\section{Coal mining policies in key producer states}

This section describes recent evolutions in the coal mining policies of China, the USA, Australia and India. For each case, we proceed in a similar fashion: we describe their coal extraction policies in historical perspective, whether a ban on mining has been enacted or not, and how these policies are justified.

\subsection{China}

China has been the world's largest coal producer since the mid-1980s, when it overtook the former Soviet Union (BP 2016). Since 1998, the government has implemented policies to shut down illegal small-scale coal mines, whose rising output had helped to create an oversupply problem and posed safety and environmental risks (Shen and Andrews-Speed 2001). The coal phase-out policy has been strengthened in every subsequent 5-year plan, bringing about the closure of 16,866 small coal mines between 2006 and 2015 (Duan 2016). Recently, China has 
stepped up its efforts and has also put a ban on the opening of new mines. In September 2015, the National Development and Reform Commission (NDRC) banned coal mines in eastern regions and issued stricter approval requirements for other regions (NDRC 2015). In December 2015, the ban on coal mines was extended to a 3-year moratorium on any new mines (Ziman 2015). And in February 2016, the State Council announced that China would eliminate 500 million tons of coal mining capacity within 3-5 years (State Council 2016). China further explicitly focuses on controlling coal consumption in its NDC, as submitted under the Paris Agreement.

Although these curbs on coal extraction followed in the wake of the Paris Agreement and of global civil society calls for a global moratorium, the decision does not seem to be inspired by it. Cutting industrial overcapacity and economic restructuring are the overarching rationale behind the country's moratorium and related capacity cuts. The move comes amid a structural shift in China's economy toward the 'new normal' of slower growth rates, while realigning itself on a consumption-led growth path away from energy intensive industries, including steel, coal and construction, and amid reports that China's coal consumption has effectively peaked (Qi et al. 2016). However, under its 'Belt and Road Initiative', production for the domestic market might stabilise or even decrease, yet China could also rebrand itself as a regional and global exporter of coal and coal-fired power plants (Mathews and Tan 2017).

\subsection{The USA}

The second largest coal producer, the USA, issued a moratorium on coal mining approvals on federal lands in the early 2016. More precisely, the Secretary of the Interior, Sally Jewell, ordered a programmatic review of the federal coal lease programme in January 2016, which was likely to take 3 years for completion. During this period, no new coal leases for federal lands would be granted. Plummeting prices and production levels, cheap(er) natural gas and renewables, as well as an overall reluctance to invest in the sector eased the implementation of a moratorium (Marino 2016). Yet, this moratorium remained largely symbolic. It only affected mining on federal lands, which fall under the jurisdiction of the Department of the Interior (DOI) and its agency responsible for the administration of public lands, the Bureau of Land Management (BLM), and thus does not affect the approximate $60 \%$ of total coal production coming from non-federal lands in the USA. Moreover, the pause did not apply to existing production activities, metallurgical coal mining, small lease modifications, and emergency modifications (Secretary of the Interior 2016). Additionally, the USA did not mention coal in its NDC proposed under the Obama administration.

As was the case for China, despite being announced shortly after the call for a global moratorium, no reference was made thereto when the US moratorium was announced. The DOI identified the following issues as the most pressing to be addressed by the review: (1) a fair return for American taxpayers; (2) climate and environmental policies, including price adjustments based on externalities; (3) the interests of the coal industry, plagued by overcapacity, and of the coal workers (Secretary of the Interior 2016). The US moratorium (very much like the Chinese) was thus framed mostly as a domestic issue, and it was in no way flanked by calls for a global moratorium.

\subsection{India}

In 2015, the government announced ambitious plans to rake up production to 1.5 billion tonnes by 2020 (IEA 2015, p. 514). The state-owned miner (and largest coal mining 
corporation in the world), Coal India Limited (CIL), is set to contribute 1 billion tonnes to this target. To meet this production target, the government is counting on capacity addition from new mining projects (Ministry of Coal 2016). Yet, officials have already backtracked on this target amid slow economic growth and slower-than-expected growth in power demand. Moreover, in December 2016, the government launched its draft National Electricity Plan, according to which there is no need for new coal-fired power plants beyond the 50-GW coal fleet that is currently under construction, until at least 2027.

Two narratives dominate coal mining policy in India. First, the narrative of self-sufficiency. In 2015, India became the world's largest coal importer (ITC 2017), and large exporters such as Indonesia and Australia have been eyeing India as a growing export market in the years to come (Connor 2016). Second, the current government intends to rely mostly on coal for energy poverty alleviation (Rosewarne 2016). This is also reflected in the country's NDC. Coal, in short, is seen as a key to the country's sovereignty and modernity (Lahiri-Dutt 2016). In contrast with China, India has far less robust action plans in place for emission reductions and the peaking of coal consumption. The NDC and current policies exemplify the pro-coal political economic environment which stands in the way of adopting a coal mining moratorium.

\subsection{Australia}

In Australia, the largest coal exporter in the world, the government is firmly opposed to a moratorium, despite the country being home to the 'No New Coal Mines' campaign, one of the most vocal advocacy campaigns in favour of a ban. In reaction to this campaign, spearheaded by TAI, and an open letter signed by dozens of prominent Australians advocating for a ban on new mines and expansion of existing ones (Taylor 2015), the Australian prime minister, Malcolm Turnbull stated that '[an export moratorium] would make not the blindest bit of difference to global emissions, because importers would buy it from elsewhere' (Hurst 2015).

The Australian government further argues that its coal exports are critical in alleviating energy poverty and in 'promoting prosperity around the world' in general (Hurst 2015). In the midst of discussions around the approval of the planned Adani Carmichael mine in Queensland, the Minister for the environment emphasised that there is a 'strong moral case for coal' (Milman 2015). It is considered an indispensable resource to provide universal energy access, as envisaged by the United Nations Sustainable Development Goals. In addition, coal projects such as the Carmichael mine are believed to 'create thousands of jobs and [it will] see billions of dollars invested into those regional economies' (Milman 2015). Australia's continued support for coal mining is thus framed as both a moral obligation to provide 'clean coal' and an economic necessity to provide national jobs and economic growth (Baer 2016; Rosewarne 2016). The Australian NDC does not refer to coal at any point.

Table 2 provides a schematic overview of the abovementioned positions and arguments.

\section{Explaining diverging policies}

Rather than taking these official policy rationales at face value, in this section, we 'dig deeper' to uncover the key ingredients that make up the different political economies of coal in the cases under consideration, including interests, ideas and institutions. The goal is to comparatively identify the driving forces of coal policies in these four countries, in order to explain 


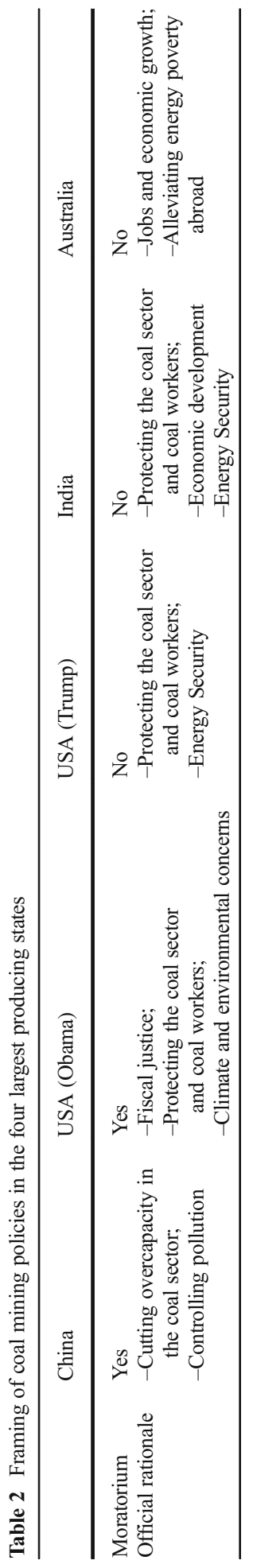


policy divergence, but also to assess whether the recent moves to ban new coal mines in China and the USA are merely transitory or whether they signal a deeper process of a changing normative environment, which could assist the emergence and diffusion of a global moratorium on new coal mines.

\subsection{Interests}

Interests can be defined as 'real, material interests of principal actors, whether conceived as individuals or groups' (Hall 1997, p. 176). Policies or regulations can be designed in pursuit of maximising the public interest (rather than that of individuals, groups or sectors), they can be inspired by particularistic concerns of certain interest groups, which can result in what is called 'regulatory capture' (Stigler 1971) by an industry, or they can result from politicians' own electoral aspirations (see Hall 1997). In the context of coal mining policies, public interests may include a wide variety of concerns such as job creation and economic development, as well as environmental considerations.

Despite differences in their economic models, in all four countries, the state is a central actor in coal extraction decision-making. Yet, this does not mean that it will always solely act on behalf of the 'public interest'. A case in point is the USA, where the moratorium was the outcome of a complex institutional consultation model between the state (represented by the DOI and BLM), the coal industry and (environmental) advocacy groups. Government reports focused on the uncompetitive nature of the bidding process and securing public revenue, the climate and environmental pollution argument was supported by environmental advocacy groups, while the industry wished to maximise profits, and coal communities aimed at averting job losses (DOI 2017, pp. 27-28). Electoral party interests also affected policy outcomes. Under the new Trump Administration, the moratorium was cancelled as the interests of the coal industry (and its workers) took centre stage, while climate considerations were completely discarded.

In China, the state-led coal sector has been undergoing reform for some years through consecutive top-down imposed 5-year plans for economic and social development. Initially, these plans and their sectoral sub-plans focused on safeguarding the interests of the stateowned coal mines vis à vis the small, local, and illegally operating township and village mines - e.g., through a state-led consolidation movement (Shen and Andrews-Speed 2001). The aim of the current thirteenth 5-year sub-plan for the coal industry is to reduce overcapacity and inefficiency, as well as to produce cleaner coal to improve air and water quality (Platts 2017). Chinese coal workers have already taken the streets to protest against Beijing's longterm plans for downsizing the coal sector in a push for their collective interests (Hornby 2016). In the USA, coal workers also felt disadvantaged by the moratorium and supported Trump's electoral campaign.

In Australia, the government's opposition to a mining moratorium mainly stems from a focus on coal as an export commodity. Coal accounted for $12.8 \%$ of Australia's total goods and services exports in 2016, making it the nation's second largest export income earner after iron ore (Department of Foreign Affairs and Trade 2017). Furthermore, Australia's coal industry continues to benefit from the lack of alternatives to metallurgical coal for global steel production, and the world's ongoing reliance on coal for power generation (Lucas 2016). Initiatives such as the Australia Institute's 'No New Coal Mines' campaign have so far failed to bear much influence on the government's coal extraction policies. Australia's historical procoal state-industry nexus, especially in New South Wales and Queensland, where almost 98\% of Australia's black coal is produced, as well as the industry's export orientation explain the 
centrality of the coal industry's interests in policy formulation. Moreover, just like the Trump administration, the Australian government frames coal as an essential job-creating sector in the public's interest, despite official accounts not substantiating any such claims (Denniss et al. 2016). Yet, the industry is not acting as a monolith in defence of its interests. Incumbent industrial actors have voiced their discontent over the proposed Adani coal mine. The Port of Newcastle for example, the world's largest coal export port, opposes the plans claiming it will destroy jobs and drive coal prices down in an already shrinking market. Moreover, Australia's second largest bank, Westpac, recently issued new lending criteria, declaring it would limit lending for new thermal coal projects to existing coal producing basins only. ${ }^{4}$ In short, based on rational self-interests, these financial and industry actors are already supporting a moratorium on new coal mines in all but name. Therefore, powerful 'unlikely' coalitions between incumbents and climate campaigners could help ease the implementation of a moratorium.

The Indian government's main concern is the expansion of the country's electricity generation capacity in view of its economic development. It relies on the presumption that for the material well-being of its citizens, i.e., the public interest, coal development is indispensable. Economic and development interests seem decisive in the country's decisionmaking on coal mining (Lahiri-Dutt 2016). Because of subsequent failures in boosting national coal production, both public and private Indian mining companies are internationalising their activities to secure a global coal supply chain (Rosewarne 2016). ${ }^{5}$ Given Australia's particular political economy of coal, India is eyeing Australia's coal resources for its development, while vice versa Australia sees India as a potential key export market for its consolidation as an energy 'superpower'.

In general, all countries use similar frames of interests in order to rationalize their policies. They attempt to align public interests of economic development and job creation with those of their respective industries' need for profit maximisation.

\subsection{Ideas}

(Party-) ideologies and worldviews also play a vital role in regulatory design (Hall 1997; Baldwin et al. 2012). In the case of coal mining, a crucial set of ideas relates to the ideological questions of how the economy should work and could be steered accordingly. In other words, where do respective political economic policy preferences come from, what are the beliefs and norms that underpin these convictions, and how should the government fulfil its role in the economy (Houle et al. 2015, p. 55)? Next to ideology, ideas can also relate to broader moral convictions of 'what is right'.

China's political economy is built on the assumption that the state, as the embodiment of the Chinese people, is the only actor that has decision-making power in implementing economic or climate policies. Hence, the 'socialist' market economy can be shaped to align traditional economic objectives of growth and reform with environmental goals of improving air quality and mitigating the effects of climate change (McNally 2012). In order for this policy to be successful, the moratorium and other coal mining measures (capacity cuts, mine closures, consolidations, etc.) that have been announced in recent years were linked to the material

\footnotetext{
${ }^{4}$ Interview with Richard Denniss, Chief Economist, The Australia Institute, 29 August 2017. This would mean that the Galilee Basin, where the proposed Carmichael mine is located, would not be eligible for funding by Westpac. Three other large Australian banks had already distanced themselves from financing the Adani project prior to Westpac's decision (Robertson 2017).

${ }^{5}$ E.g., Adani (Indian company) and its attempts to open the Carmichael mine in Queensland, Australia.
} 
economic interests of sustaining solid growth figures. Further, in 2007, the Premier Hu Jintao announced that China would become an 'ecological civilisation', eschewing the previous development model that had seen economic growth be prioritised over the environment. This meant a fundamental ideational shift in the construction of notions such as 'growth' and 'development' (Guangyao 2016).

In the USA, the ideational conflict does not so much centre around the role of the government with(in) the coal economy, as it does around the basic science of climate change. Market forces have always been key to the energy transition, according to the former President Obama (2017), who was nevertheless accused by current President Trump of waging a 'political war on coal'. Under consecutive administrations, even those that considered climate change as a fundamental political concern, political consensus in the USA has always been that of enhancing market-based solutions to energy and climate issues. The coal mining moratorium is a case in point, since it only went as far as to include coal mines located on federal lands, not those on private (or state-owned) lands. The fundamental ideational difference between the two administrations is that President Trump does not underscore the nearuniversal scientific consensus on anthropogenic climate change, the idea that the current changes in climatic conditions are caused by greenhouse gas emissions generated by human activities. Prior to his presidency, he repeatedly criticised the concept of climate change, calling it a 'hoax', 'non-existent' or 'mythical'. As a consequence of these beliefs, President Trump announced the USA's withdrawal from the Paris Agreement in June 2017 (Baker 2017; Urpelainen and Van de Graaf 2017).

Ideational preferences and beliefs also help explain successive Australian governments' support for the coal industry. In spite of environmental opposition, as well as genuine concerns about the economic viability of new coal projects, the government remains convinced that "expanded development of the economy is tied to extracting and exporting fossil fuels, to consolidating Australia as an "energy superpower" (Rosewarne 2016). The government continues to play an enabling role in the development of (private) coal projects and the internationalisation of Australia's coal economy. Moreover, in both Australia and India, there is a shared ambition of increased extraction and burning of coal as the foundation of national economic development. This belief of 'coal developmentalism' concurs with the material interests of both countries and the increasing integration of both coal economies, despite calls in India to temper its dependence on foreign coal (Rosewarne 2016).

The Indian Ministry of Coal, in cooperation with the state-owned enterprise Coal India Limited, which contributes about $81 \%$ of total coal production in India, set production targets for the industry, reflecting its large impact on the sector and the determining pro-coal, interventionist role of the government in the coal economy (Lahiri-Dutt 2016). Moreover, the Indian government believes that it is their moral right and obligation to provide their population with coal-fired power as to alleviate widespread (energy) poverty.

\subsection{Institutions}

The policy divergences might also stem from differences in the organisational structure of the political economy (Hall 1997). 'Institutions' is a category that does not (only) refer to tangible organisations such as legislatures, courts, executives, etc. Instead, institutions can also be described as humanly devised social constraints that shape human (inter)action (Baldwin et al. 2012, p. 53). The openness of a political system toward particular interests, for example, might be an important factor, one that could mediate the impact of advocacy and lobbying (i.e., private interests). 
China has a one-party political system. While the ruling party is not immune for pressures emanating from society, see for example its pragmatic responses to rising public concerns over coal-induced air pollution, the country's polity is more closed compared to democratic societies to such pressures. The main administrative authority, the State Council, by means of the NDRC, formulates and implements the strategies of economic development, resulting in highly concentrated and asymmetrical decision-making power (Peng 2015). This might explain why the government could push forward its plans to restructure the coal industry, defying protests and manifestations from the many mine workers who fear losing their jobs as a result of the government's policies.

What is striking about the US institutions, is that it is not the Department of Energy or Environmental Protection Agency that has implemented the moratorium but rather the DOI and its affiliate, the Bureau of Land Management. The reason is that the DOI has authority over federal, public lands, accounting for approximately $40 \%$ of the countries' total coal production. This might explain why the moratorium has been framed more in terms of fiscal justice and competitiveness, rather than in energy or environmental terms. The US' institutional set-up also explains the limited reach of the moratorium. Although a broad collection of federal, state and tribal laws govern the mining and use of coal in the United State, the federal government does not have the capacity to enforce the moratorium, since it falls outside the scope of the federal coal lease programme.

In India, the government is the principal energy market agent, with responsibility for both setting energy policies and administering the public companies that produce energy. It has a Ministry of Coal, now falling under the umbrella Ministry of Power, Coal, New \& Renewable Energy and Mines (a consolidation of ministries), ${ }^{6}$ which is the only one of its kind in the four largest producing countries. The Ministry explicitly aims to 'augment[ing] production through government companies' (Ministry of Coal 2013). With such a dedicated ministry attempting to shape the nation's energy landscape, coal has a significant impact on India's political economy (Lahiri-Dutt 2016), and it may make the government more vulnerable to 'regulatory capture'.

In Australia, state authorities are key stakeholders as well. With coal production concentrated in these regions, New South Wales and Queensland are very influential in coal policymaking. Moreover, since Australia's state governments are given wide control over the planning, development, extraction and sale of coal and other mineral resources, this level is the primary venue for industry-government interactions and possible regulatory capture (Lucarelli 2015; Baer 2016).

\section{Conclusions and discussion}

Addressing fossil-fuel supply as an effective climate policy measure has only recently started attracting attention (Lazarus et al. 2015). This article has attempted to shed light on the ideas, institutions and interests that underpin diverging coal mining policies of the four largest coal producing countries in the world. The underlying goal was to assess whether there is a

\footnotetext{
${ }^{6}$ Prior to 1992, the Ministry of Power, Coal and Non-Conventional Energy Sources consisted of three departments. In 1992, that ministry was split into the Ministry of Power, Ministry of Coal, and Ministry of Non-Conventional Energy Sources (rechristened the Ministry of New and Renewable Energy in 2006), overseen by the same Minister and with interdependent competencies.
} 
normative shift away from the view that the extraction of coal constitutes 'appropriate' behaviour.

The analysis shows that climate change considerations are not yet factored into coalextraction policies. Australia and India have ambitious plans to expand coal production, largely because of domestic economic concerns. The Australian conservative government puts strong emphasis on increasing coal exports (and related revenues) in an effort to boost the national economy. A similar version of such 'coal developmentalism' is found in India, where the absence of a moratorium can partly be explained by the near-monopolistic position of stateowned CIL, coupled with the country's drive for self-sufficiency; imposing a ban on the opening of new coal mines would thus not help the incumbent (since CIL dominates the market), and it could lead to more imports over time.

Even in China and the USA, countries that have or had temporary bans on new coal mines, climate considerations played second fiddle and there is little to no evidence that normative ideas regarding coal extraction have shifted, assisting in the emergence of a global anti-coal mining norm. Instead, the current Chinese and US coal extraction policies can best be explained as strategic moves to protect the industry from the headwinds it is facing. The Chinese moratorium's main purpose was to serve as industrial policy to combat growing overcapacity, and it might be easily overturned (or simply cease to exist after 3 years if it is not prolonged). The temporary ban under the previous US administration was primarily motivated by concerns over fiscal justice rather than climate justice.

Beyond the countries studied here, it should be noted that a coal mining moratorium has also recently been discussed in Indonesia and Myanmar. In Indonesia, a moratorium on new coal mining concessions was proposed in April 2016. The President framed the plan as an environmental measure, an extension of the 2011 forestry moratorium, but it is clear that a licencing freeze would also neatly extend the government's efforts to prevent over-mining and preserve coal reserves for future consumption (Cornot-Gandolpe 2017). In Myanmar, the government announced that it would stop issuing new coal mining leases due to coal's harmful effects on health. ${ }^{7}$

These particular national cases demonstrate that national circumstances and sensitivities are key in debates about (curbing) coal extraction. Recent developments in global climate governance also highlight a '(re)turn to the state' (see, e.g., Purdon 2015; Green, this issue). The 2015 Paris Agreement institutionalised the logic of domestically driven climate action through voluntary nationally determined contributions. Indeed, the domestic sphere has become the primary institutional setting where relevant political actors interact, contest, negotiate and bargain on climate-related political issues (Falkner 2016).

In short, the emerging anti-coal extraction norm struggles to gain political traction due to firmly entrenched material interests, political constellations, beliefs and institutions. Despite the compelling logic of the carbon budget and the resulting amounts of 'unburnable' coal, a global treaty prohibiting the opening of new coal mines - comparable to, for instance, the Minamata Convention which phases out mercury mining - remains a distant prospect. While there is scope to increase international moral pressure through the Paris process (e.g., countries could include coal mine moratoria, fracking bans, etc. in their NDCs), ${ }^{8}$ our analysis suggests that the domestic political arena is the key for the success of any campaign that aims to stymie

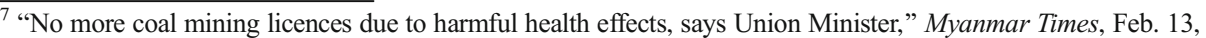
2017.

${ }^{8}$ Many thanks to Richard Denniss for highlighting this.
} 
future coal production. Proponents of a global coal moratorium should have a greater chance of overcoming opposition to the extent that they succeed in framing the issue in non-climate terms (e.g., fiscal justice, energy conservation, industrial policy, public health), which would expand the domestic political coalition in favour of a ban on new coal mines.

\section{References}

Baer HA (2016) The nexus of the coal industry and the state in Australia: historical dimensions and contemporary challenges. Energy Policy 99:194-202

Baker P (2017) Does Donald Trump Still Think Climate Change is a Hoax? No one Can say. https://www. nytimes.com/2017/06/02/us/politics/climate-change-trump-hoax-scott-pruitt.html. Accessed 28 August 2017

Baldwin R, Cave M and Lodge M (2012) Understanding regulation: theory, strategy and practice. Oxford University Press, Oxford

BP (2016) Statistical review of world energy 2017. BP, London

Clapp J, Swanston L (2009) Doing away with plastic shopping bags: international patterns of norm emergence and policy implementation. Environ 18(3):315-332

Connor LH (2016) Energy futures, state planning policies and coal mine contests in rural New South Wales. Energy Policy 99:233-241

Cornot-Gandolpe S (2017) Indonesia's electricity demand and the coal sector: export or meet domestic demand? OIES Paper CL 5, March 2017. Oxford Institute for Energy Studies, Oxford

Denniss R (2015) Launch of No New Coal Mines. The Australia Institute. http://www.nonewcoalmines.org. $\mathrm{au} /$ launch of no new coal mines. Accessed 11 September 2017

Denniss R, Adams P, Campbell R, Grudnoff M (2016) Never gonna dig you up! Modelling the economic impacts of a moratorium on new coal mines. The Australia Institute, Canberra

Department of Foreign Affairs and Trade (2017) Australia's trade in goods and services 2016. http://dfat.gov. au/about-us/publications/trade-investment/australias-trade-in-goods-and-services/Pages/australias-trade-ingoods-and-services-2016.aspx. Accessed 21 August 2017

DOI (2017) Federal Coal Program. Programmatic Environmental Impact Statement - Scoping Report. Department of the Interior, Washington DC

Duan H (2016) Windows of Opportunity: Coal Phase-Out in China. Paper presented at the International Conference on Fossil Fuel Supply and Climate Policy, Oxford University, 26-27 September 2016

Falkner R (2016) The Paris Agreement and the new logic of international climate politics. Int Aff 92(5):11071125

Finnemore M, Sikkink K (1998) International norm dynamics and political change. Int Organ 52(4):887-917

Florini A (1996) The evolution of international norms. Int Stud Q 40(3):363-389

Grantham Institute (2015) Nicholas Stern welcomes initiative on coal mines by Anote Tong, President of the Republic of Kiribati. http://www.lse.ac.uk/GranthamInstitute/news/nicholas-stern-welcomes-initiative-oncoal-mines-by-anote-tong-president-of-the-republic-of-kiribati. Accessed 25 August 2017

Green F Anti-fossil fuel norms. Clim Chang (this issue)

Guangyao Z (2016). Ecological Civilization. http://www.unep.org/ourplanet/march-2016/articles/ecologicalcivilization/ Accessed 7 July 2017

Hall PA (1997) The role of interests, institutions, and ideas in the comparative political economy of the industrialized nations. In: Lichbach MI, Zuckerman AS (eds) Comparative politics: rationality, culture, and structure. Cambridge University Press, Cambridge, pp 174-207

Hornby L (2016) China coal protests highlight overcapacity tensions. Financial Times. https://www.ft. com/content/1f8519fe-e8cd-11e5-bb79-2303682345c8. Accessed 1 March 2017

Houle D, Lachapelle E, Purdon M (2015) Comparative politics of sub-Federal cap-and-Trade: implementing the western climate initiative. Global Environ Politics 15(3):49-73

Hurst D (2015) Malcolm Turnbull: coal export ban 'would make no difference to emissions'. https:/www. theguardian.com/australia-news/2015/oct/27/malcolm-turnbull-coal-export-ban-would-make-no-differenceto-emissions. Accessed 20 August 2016

IEA (2015) World energy outlook 2015. IEA, Paris

ITC (2017) List of importers for the selected product: Coal, briquettes, ovoids and similar solid fuels manufactured from coal. ITC Trademap. http://trademap.org/Country_SelProduct_TS.aspx?nvpm=1 |||||2701|||4|1|1|1|2|1|2|2|1. Accessed 2 March 2017

Lahiri-Dutt K (2016) The diverse worlds of coal in India: energising the nation, energising livelihoods. Energy Policy 99:203-213 
Lazarus M, Erickson P, Tempest K (2015) Supply-side climate policy: the road less taken. Stockholm Environment Institute, Seattle

Lucarelli B (2015) Australia's black coal industry. Past achievements and future challenges. In: Thurber M C and Morse R K (eds) The global coal market: supplying the major fuel for emerging economies. Cambridge University Press, Cambridge, pp 204-293

Lucas A (2016) Stranded assets, externalities and carbon risk in the Australian coal industry: the case for contraction in a carbon-constrained world. Energy Res Soc Sci 11(1):53-66

Marino J (2016) Wall Street checks out of coal mines. CNBC. http://www.cnbc.com/2016/03/16/wall-streetchecks-out-of-coal-mines.html. Accessed 2 March 2017

Mathews J, Tan H (2017) China's new silk road: will it contribute to the export of the black fossil-fuelled economy? The Asia-Pacific J 15(8):1-14

McGlade C, Ekins P (2015) The geographical distribution of fossil fuels unused when limiting global warming to $2^{\circ} \mathrm{C}$. Nature $517: 187-190$

McNally CA (2012) Sino-capitalism: China's reemergence and the international political economy. World Politics 64(4):741-776

Milman O (2015) Josh Frydenberg puts 'strong moral case' for coal exports to prevent deaths. https://www. theguardian.com/australia-news/2015/oct/18/josh-frydenberg-puts-strong-moral-case-for-coal-exports-toprevent-deaths. Accessed 7 July 2017

Ministry of Coal (2016) All India Coal Production target for 2016-17 fixed at 724.71 MT. Delhi, Government of India

NDRC (2015) Circular on Issues Concerning Strict Control of New Coal Mining Projects. http://www.sdpc.gov. cn/gzdt/201509/t20150918_751436.html. Accessed 16 February 2017

Obama B (2017) The irreversible momentum of clean energy. Science. https://doi.org/10.1126/science.aam6284

Pacific Island Development Forum (2015) Suva Declaration on Climate Change. http://pacificidf.org/wpcontent/uploads/2013/06/PACIFIC-ISLAND-DEVELOPMENT-FORUM-SUVA-DECLARATION-ONCLIMATE-CHANGE.v2.pdf. Accessed 16 February 2017

Peng W (2015) The evolution of China's coal institutions. In: Thurber C, Morse RK (eds) The global coal market: supplying the major fuel for emerging economies. Cambridge University Press, Cambridge, pp 3772

Piggot G (2017) The influence of social movements on policies that constrain fossil fuel supply. Clim Pol. https://doi.org/10.1080/14693062.2017.1394255

Platts (2017) China's 13th Five-Year Plan for coal industry aims for more industry consolidation. http://www. platts.com/latest-news/coal/hunan-china/chinas-13th-five-year-plan-for-coal-industry-27741744. Accessed 9 January 2017

Purdon M (2015) Advancing comparative climate change politics: theory and method. Global Environ Politics $15(3): 1-26$

Qi Y, Stern N, Wu T, Green F (2016) China's post-coal growth. Nat Geosci 9(8):564-566

Robertson J (2017) Big four banks distance themselves from Adani coalmine as Westpac rules out loan. https:/www.theguardian.com/environment/2017/apr/28/big-four-banks-all-refuse-to-fund-adani-coalmineafter-westpac-rules-out-loan. Accessed 12 September 2017

Rosewarne S (2016) The transnationalisation of the Indian coal economy and the Australian political economy: the fusion of regimes of accumulation? Energy Policy 99:214-223

Secretary of the Interior (2016) Discretionary programmatic environmental impact statement to modernize the federal coal program. DOI, Washington DC

Shen L, Andrews-Speed P (2001) Economic analysis of reform policies for small coal mines in China. Resources Policy 27(4):247-254

State Council (2016) Coal capacity guideline issued. http://english.gov.cn/policies/latest_releases/2016/02/05 /content_281475284701738.htm. Accessed 16 February 2017

Stigler GJ (1971) The theory of economic regulation. Bell J Econ Manag Sci 2(1):3-21

Taylor L (2015) Prominent Australians ask world leaders to consider ban on new coal mines. https:/www. theguardian.com/environment/2015/oct/27/prominent-australians-ask-world-leaders-to-consider-ban-onnew-coalmines. Accessed 28 August 2017

UNEP (2017) Partnership for Clean Fuels and Vehicles. http://www.unep.org/transport/node/151/. Accessed 12 September 2017

Urpelainen J, Van de Graaf T (2017) United States non-cooperation and the Paris agreement. Clim Pol. https://doi.org/10.1080/14693062.2017.1406843

Van de Graaf T, Blondeel M (2018) Fossil fuel subsidy reform: an international norm perspective. In: Skovgaard J, van Asselt H (eds) The politics of fossil fuel subsidies and their reform. Cambridge University Press, Cambridge

Ziman Y (2015) No new coal mines to be approved for three years to cut stockpiles. China Daily. http://www. chinadaily.com.cn/business/2015-12/31/content_22877905.htm. Accessed 12 September 2017 